\title{
Modeling and Model-based Control of Automotive Air Paths
}

Robin Holmbom 



\title{
Modeling and Model-based \\ Control of Automotive Air Paths
}

\author{
Robin Holmbom
}

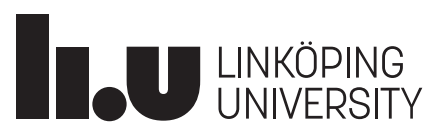

Division of Vehicular Systems

Department of Electrical Engineering

Linköping University

SE-581 83 Linköping, Sweden

Linköping 2022 
Linköping Studies in Science and Technology

Dissertations No. 2195

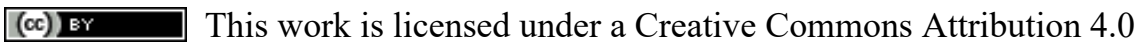
International License.

https://creativecommons.org/licenses/by/4.0

Robin Holmbom

robin.holmbomeliu.se

www.vehicular.isy.liu.se

Division of Vehicular Systems

Department of Electrical Engineering

Linköping University

SE-581 83 Linköping, Sweden

Copyright $(92022$ Robin Holmbom, unless otherwise noted.

Published articles have been reprinted with permission from the respective copyright holder.

Holmbom, Robin

Modeling and Model-based Control of Automotive Air Paths

ISBN 978-91-7929-145-7 (print)

ISBN 978-91-7929-146-4 (PDF)

ISSN 0345-7524

DOI https://doi.org/10.3384/9789179291464

Typeset using $\mathrm{LAT}_{\mathrm{E}} \mathrm{X} 2 \varepsilon$

Printed by LiU-Tryck, Linköping, Sweden 2022 
To Elin and Hjalmar 



\section{Populärvetenskaplig sammanfattning}

Förbränningsmotorer har funnits med oss länge, men det var först 1892 som Rudolf Diesel presenterade dieselmotorn. Förbränningsmotorn har ständigt utvecklats genom åren, men där fokuset för förändringen varierat över tid. Sedan slutet av 1900-talet har utsläppen legat i fokus tillsammans med bränsleförbrukningen. Där utsläppskraven främst kommit via politiska påtryckningar och bränsleförbrukningen är mer ekonomiskt driven, även fast båda dessa till viss del går hand i hand med varandra. Enkelt förklarat så går det ut på att i en förbränningsmotor se till att det finns luft, innehållande syre, för att förbränningen av bränslet ska kunna ske. Så mycket som möjligt av den energi som frigjorts vid förbränningen vill man ta tillvara på. Hur mycket av den energin man tar tillvara på bestämmer vilken verkningsgrad man har.

I denna avhandling behandlas gnisttända motorer, vilken kan används ihop med bränslen så som bensin, biogas, etanol m.fl. Efterbehandlingssystemet för att rena avgaserna från dessa motorer använder ofta en trevägsvägskatalysator, vilken kräver nästintill perfekt luft/bränsle-förhållande för att fungera. Detta ställer krav på att både luft- och bränsletillförseln har en god precision och att de är koordinerade. Denna avhandling behandlar luftstyrningen till en gnisttänd motor. Även om luftstyrningen appliceras på en gnisttänd motor så finns det andra tekniker som kan dra nytta av arbetet som till exempel bränsleceller, där bränslecellerna behöver förses med luft för att kunna reagera med vätgasen och bilda elektricitet, värme och vatten.

I och med den starka koppling som finns mellan luft- och bränsletillförseln, så är momentet som motorn levererar också starkt kopplat till lufttillförseln. För en förare så är tillräckligt stora momentförändringar kännbara, vilket gör att luftstyrningen påverkar körbarheten. Traditionellt har momentstyrningen ofta handlat om att leverera ett moment så snabbt som möjligt och på ett sätt som uppskattas av föraren. I och med utvecklingen av laddhybrider där elektriska motorer samt förbränningsmotorer båda påverkar fordonets drivlina, är inte alltid den traditionella styrningen den mest önskade utan det kan handla om att momentet från förbränningsmotorn behöver följa ett visst fördefinierat svar, som arbetar ihop med den elektriska drivlinan.

För den gnisttända motorn har mängder av olika nya motorkonfigurationer innehållande delsystem så som avgasåtercirkulering, turboladdning, variabla ventiltider, m.fl, som alla påverkar luftens väg in till förbränningen tillkommit. Utöver att förbättra både bränsleförbrukning och utsläpp så blir regleringen svårare där fler delsystem påverkar varandra. För att få en bra reglering behöver reglersystemet kunna hantera koordinationen av de olika delsystem så att de 
arbetar tillsammans, och inte mot varandra.

För att kunna följa med i den ständiga utvecklingen och förändringen av motorkonfigurationerna utan att behöva göra om hela modelleringen för enskilda konfigurationer, så har avhandlingen valt att rikta in sig på en modellbaserad metodik över de olika komponenterna. Det är inte bara nya delsystem som utvecklas utan även de befintliga systemen förbättras, så som att styrdon blir snabbare och mer exakta. Ett exempel på detta studeras i den första delen av avhandlingen där ett elektriskt servo för styrningen av wastegaten, ventil som kan omleda avgaserna förbi turbinen, jämförs mot det mer traditionella styrdonet för wastegaten drivet av en tryckskillnad över ett membran.

Kompakta modeller är ofta av intresse för reglerdesign då de håller nere beräkningskraften som krävs, vilket gör att en avvägning mellan noggrannhet och kompakthet hos modeller görs. Luftmassflöden utgör den centrala delen av luftstyrningen vilket gör att andra delen av avhandlingen undersöker kompakta modeller för luftmassflödena. Jämförelse av olika modeller för kompressibelt flöde genom en ventil, likt en trottel, görs, samt modellering av massflödet genom insugs- och avgasventilerna utgör denna del av avhandlingen.

Sista delen av avhandlingen behandlar olika typer av reglerdesigner baserade på modellpredikterad reglering där önskad position för de olika styrdonen bestäms för att uppfylla olika krav. En simuleringsstudie presenteras där trotteln regleras samtidigt som det finns ett krav på maxtemperaturen i insugsröret till följd av den kompression som sker vid en positiv trycktransient. Även en hel implementation i Linköping universitets motortestcell presenteras där en reglering som koordinerar både trotteln och insugskamfasningen presenteras. Där det finns ett krav på att insugskamfasningen måste följa ett visst insugstryck samtidigt som begärt insugstryck uppnås. 


\section{Abstract}

The strive towards cleaner and more efficient combustion engines, driven by legislation and cost, introduces new configurations, as exhaust gas recirculation, turbocharging, and variable valve timing, to name a few. Beside all the positive effects on the emissions and fuel consumption, they all affect the air-charge system, which increases the cross-couplings within the air-path control, making it an even more complex system to control. As the SI engine uses a three-way catalytic converter, which enforces a condition of stoichiometric combustion, the amount of air flow and fuel flow are connected. This means that the air flow has a direct impact on the driveability of the engine, through the torque.

As configurations are constantly improved or added, a component and modelbased methodology is chosen in the thesis, as it would bring flexibility and the possibility to reuse previous developments. As it enables the engineers to keep down the development cost and at the same time bring along knowledge of the systems through the model's descriptions.

The air-charge system's task is to supply the combustion chamber with the correct air mass flow, in the most energy efficient way. To be precise in the control of the air mass flow, the actuators are also constantly developed and becoming both faster and more precise. One example of this is in the first part of the thesis, where an electric servo controller for the wastegate actuation is implemented and compared against the more traditionally used actuator, controlled through a pressure difference over a membrane. As the focus for the air-charge system is the control of mass flows, how these flows can be represented by compact models is also investigated in the thesis, as compact models are beneficial for control from a computation time perspective. In the last part of the thesis a simulation study for controlling the intake manifold pressure, with a constraint on intake manifold temperature, using the throttle as actuator is investigated. Lastly, an implementation of a model predictive controller acting as a reference governor, for the throttle and intake cam phasing, in an engine test cell is demonstrated. As the controller only acts as a reference governor it makes it possible for an engineer to develop the actuator controllers independently if a closed loop model of the actuator system is supplied to the controller. The coordination, of the two actuators, is solved by letting the intake cam phasing depend on the intake manifold pressure, that is a state. 



\section{Acknowledgments}

First and foremost I would like to thank all co-workers at the Division of Vehicular Systems during my $\mathrm{PhD}$ studies. I also want to thank my supervisor Lars Eriksson for giving me the opportunity of pursuing a $\mathrm{PhD}$ degree and introducing me to the world of research. I also want to thank him for all his guidance over the years and for his open door policy. Daniel Jung is acknowledged for being my co-supervisor. Erik Frisk is acknowledged for all the times answering questions, even though he might have been busy. Tobias Lindell is acknowledged for all his help in the engine lab with exchanging engine parts at short notice, and assisting with measurements. Marcus Rubensson and Fredrik Wemmert are acknowledged for their valuable discussions over the years.

Throughout the years during the $\mathrm{PhD}$ studies I have learned how to make fantastic pizza and perfect burgers. I have also been introduced to road cycling. All this I have to thank Kristoffer Ekberg, Olov Holmer, and Viktor Leek for. There have also been a lot of work related topics in our discussions, just ask our partners.

My son Hjalmar is acknowledged for all those times he pushed me into taking a nightly walk with him to clear my mind, and the times he got me to wake up, even if I just wanted to lay in bed a little longer. However, even if you are just about 1 year old at the time I write this, I want you to know that it was a joy coming home to your smile during the time of writing this thesis, it gave me much needed energy.

Last but not least, I would like to thank my wife Elin, for being there by my side all the way, and I would not have made it without her love and support. I love you.

Linköping, December 2021

Robin Holmbom

\section{Funding}

Linköping Center of Informatics and Control LINK-SIC is acknowledged for partially funding the research. This work was also partially supported by the project Advanced Automotive Aircharge Integration (AVATAR), between Linköpings universitet and Volvo Personvagnar AB under the Strategic Vehicle Research and Innovation (FFI) program. 



\section{Contents}

1 Introduction 1

1.1 Motivation \& Aim . . . . . . . . . . . . . . . . 3

2 Background 5

2.1 Control Objectives in Engine Control . . . . . . . . . 5

2.2 Engine Models . . . . . . . . . . . . . . . . . . . 6

2.3 Cross-Coupling Effects $\ldots \ldots \ldots \ldots \ldots$

2.4 Turbo Control . . . . . . . . . . . . . . . . . 8

2.5 Model Predictive Control . . . . . . . . . . . . . . 9

$3 \quad$ Publications and Contributions $\quad 11$

3.1 Publications . . . . . . . . . . . . . . 11

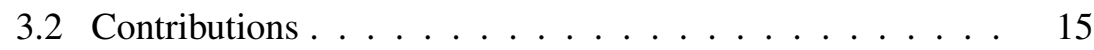

$\begin{array}{ll}\text { References } & 17\end{array}$

$\begin{array}{ll}\text { Papers } & 21\end{array}$

I Investigation of Performance Differences and Control Synthesis for Servo-Controlled and Vacuum-Actuated Wastegates 23

1 Introduction . . . . . . . . . . . . . . . . 24

2 Experimental Setup . . . . . . . . . . . . . . . . 25

3 Modeling of Actuators . . . . . . . . . . . . . 25

4 Controller Design . . . . . . . . . . . . . . . 33

$5 \quad$ Results . . . . . . . . . . . . . . . 38

6 Discussion ...................... 44

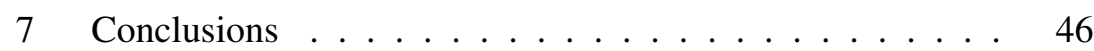

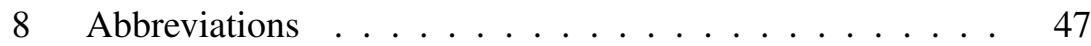

References.................... . . 47 
II Analysis and Development of Compact Models for Mass Flows Through Butterfly Throttle Valves 49

1 Introduction ... . . . . . . . . . . . 50

2 Experimental Setup .............. 51

3 Experimental Data ............. 53

4 Models ....................... 57

5 Comparison of Models .............. . . 62

6 Results ................... . . 64

7 Discussion ................. 69

8 Conclusions ...................... 70

References .................. . . 71

A Relative Errors .............. 72

III Development of a Control-Oriented Cylinder Air-Charge Model for Gasoline Engines with Dual Independent Cam Phasing 77

1 Introduction . . . . . . . . . . . . . . 78

2 Experimental Setup .............. 80

3 Simulation Model . . . . . . . . . . . . . 82

4 System Analysis . . . . . . . . . . . . . . . 89

5 MVEM Model Description ............. 97

6 Results ................... 103

7 Discussion .................. 110

8 Conclusions ..................... 111

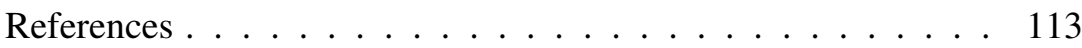

IV Throttle Control using NMPC with Soft Intake Temperature Constraint for Knock Mitigation 115

1 Introduction . . . . . . . . . . . . . . . 116

2 System Description . . . . . . . . . . . . . 117

3 Model Predictive Control . . . . . . . . . . . . . 121

4 Results .................... . . 124

5 Conclusions .................. 131

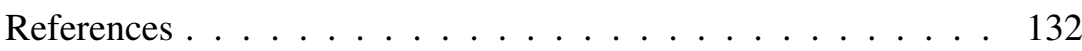

V Real-Time Implementation of Non-linear MPC in Embedded Control for Engine Air-charge Throttle and Intake Cam Phase Actuators

1 Introduction . . . . . . . . . . . . . . . 136

2 Experimental Setup ................ 138

3 Control Objective . . . . . . . . . . . . . . . . . 139 
4 Actuator Control . . . . . . . . . . . . . . . . . . . 140

5 System Model . . . . . . . . . . . . . . . . . . . . . . 143

6 Model Predictive Control . . . . . . . . . . . . . . . . 152

7 Results ...................... 156

8 Conclusions . . . . . . . . . . . . . . . . . . . 169

References . . . . . . . . . . . . . . . . 170

A Model Predictive Control Definitions . . . . . . . . . . 172 



\section{Chapter 1}

\section{Introduction}

Transportation is an important element in the daily life of humans. Unfortunately, this is seen in the emissions of greenhouse gases (GHG), and in 2020 it was estimated that global transports were responsible for $24 \%$ of direct $\mathrm{CO}_{2}$ emissions from the combustion of fuel [1]. In Sweden the transport sector in 2019 was accounted for $32 \%$ of Sweden's territorial emissions of carbon dioxide equivalents, $\left(\mathrm{CO}_{2} \mathrm{e}\right)$, which is a measure of greenhouse gas (GHG) emissions [2].

In 2015, 196 Parties signed the Paris Agreement at COP 21, 21 st Conference of the Parties (COP) [3], with the goal of limit the global warming to below $2{ }^{\circ} \mathrm{C}$, and preferably to $1.5^{\circ} \mathrm{C}$, compared to pre-industrial levels. The Paris Agreement was the first time all nations in the United Nations Framework Convention on Climate Change (UNFCCC) came into a binding agreement to combat climate change [4]. The Paris Agreement increased the focus on GHG emissions, and since then the drive towards zero emission vehicles has become strong. During COP 26, 26th COP [5], in 2021, the Swedish Government made a commitment to a declaration for $100 \%$ zero emission vehicles by 2040 , or earlier. In this declaration, zero emission vehicle means zero GHG emissions at the tailpipe. Automotive car manufacturers like Volvo Cars, Ford Motor Company, General Motors, etc. also made a commitment to the declaration [6]. The Swedish Government has also, as well as the heavy-duty truck manufacturer Scania, endorsed the global Memorandum of Understanding for zero-emission vehicles by CALSTART, recognizing that all sales of vehicles in 2040 should be powered by $100 \%$ fossil-free energy [7, 8]. It is obvious that the climate change debate is pushing for newer and cleaner technologies in the transport sector. 
For a combustion engine, the tailpipe $\mathrm{CO}_{2}$-emission is proportional to the fuel consumption and as long as the combustion is kept at stoichiometric conditions, air-to-fuel equivalence, the SI-engine can rely on the after-treatment system, a three-way catalyst (TWC) and a particle filter, to handle the other pollutant emissions beyond $\mathrm{CO}_{2}$. However, stoichiometric conditions are not always possible to fulfill and fuel enrichment has been widely used for high loads and speeds, to limit the exhaust temperature and to protect against knocking, and overheating of the catalyst [9-11]. As the fuel enrichment both increases the fuel consumption and also the emissions of $\mathrm{CO}$ and $\mathrm{HC}$, configurations involving water injection, and exhaust gas recirculation (EGR) have been given attention [11-14].

Another way to decrease $\mathrm{CO}_{2}$-emission is by increasing the engine efficiency. Configurations decreasing mainly the pumping work are usually the ones affecting the automotive air path. Some examples of these configurations are variable valve timing, downsizing through boosting, and EGR [15-18].

Configurations affecting the EGR, can be used in the throttled region of the engine to improve the efficiency by reducing the pumping losses. The pumping losses are reduced by lowering the volumetric efficiency of the engine, which is the engine's ability to fill the cylinders with fresh air. When the volumetric efficiency decreases, the air flow decreases as well, which increases the intake manifold pressure. However, too much residual gases may affect the combustion efficiency, and in some cases even cause engine misfire. The limit of dilution of residual gases, when it affects the combustion efficiency too much, is at around $2 \% \mathrm{CoV}$ of IMEP $[9,19]$, coefficient of variation $(\mathrm{CoV})$ of indicated mean effective pressure (IMEP). [20] states that pollution emissions are mainly generated as a result of imperfect combustion in internal combustion engines, which is something new control strategies and configurations can affect.

Real driving emissions (RDE), [21, 22], have received more attention and therefore the transient emissions have become more important to keep low, as the transients during real driving are not as predictable as for a predefined drive cycle. To continue fulfilling the more stringent legislation demands, configurations are added to the engine, and many of them affect the automotive air path, which becomes more complex to control. 


\subsection{Motivation \& Aim}

How to control an engine in stationary operation for the best fuel efficiency and lowest emissions, are usually calibrated through extensive engine testing in an engine test cell. In theory, models with very high model fidelity of a certain engine could be used to find these optimal values in stationary operation. This would have the possibility of reducing calibration time in an engine test cell. However, in practice, a combination of simulations and engine tests would probably be used, where the simulations help to narrow down the number of tests to find these optimal values in stationary operation. This procedure applies to already set engine designs. From a development and control perspective of the air path, two main questions arise:

1. How to control the air path between these stationary operation points?

2. How can the air path configuration be changed for better efficiency and performance?

Models give the opportunity to investigate these questions before the engine is produced.

For (1), models would describe how the engine is affected by the available control commands. If the models are control-oriented, there is a trade-off between model fidelity and model order, for it to be realizable in the controller in real-time. In the controller design the models give information about crosscouplings, dynamics, constraints, etc.

For (2), from an air path perspective, it could be to add/change components such as, turbocharger, variable valve configuration, actuators, EGR system, etc. If component based models exist, it becomes a task of combining the different models, that can easily be changed or removed, assisting in the understanding of how the system is affected by different components. If these models have physical insight, there is also a possibility of changing component design parameters without the need to re-parameterize the full model.

The aim of this thesis is therefore, to investigate and demonstrate how a component and model-based methodology could aid in the development. The thesis will be on actuator control, development of control-oriented mass flow models, and how to use this knowledge to handle cross-couplings in the control and to fulfill the set control objective. 



\section{Chapter 2}

\section{Background}

This chapter aims at bringing a short introduction into the various topics that are the focus of this thesis. Motivating the aim of this thesis that is, component and model-based methodology for air path control.

\subsection{Control Objectives in Engine Control}

The main objectives for engine control loops were stated in [23] as

1. The driver's demands for immediate torque response, good drivability, and low fuel consumption must be met.

2. The engine must be kept in a safe operating region where damage to or fatigue of the material is avoided. Knocking must be prevented, the catalytic converter must not overheat, etc.

3. The emission limits must be met. In the case of SI engines, this requires a rapid light-off of the catalytic converter, precise stationary air/fuel ratio control, and good compensations of the transient phenomena.

In the third objective above, to fulfill the emission limits an SI engine uses a three-way catalytic converter (TWC), which imposes a condition of stoichiometric combustion, air-to-fuel equivalence. This condition results in that the air inducted is proportional to the torque of the engine, which makes a connection between the first and third objective. In addition to the main objectives above, the authors of [23] presents an engine calibration procedure, where the control objective is to minimize the fuel consumption while having constraints on the emissions, over a driving cycle. 


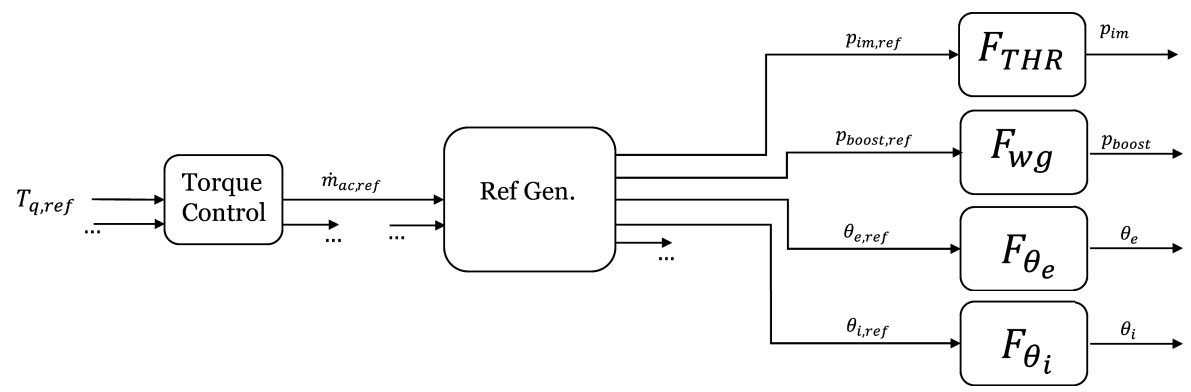

Figure 1: Conceptual air-charge control design of individual SISO controller, where $F_{x}$ is each individual SISO controller for system $x$. Ref.Gen symbolizes the reference generator for the SISO Controllers and Torque Control symbolizes the overall torque controller. $\dot{m}_{a c}$ is the mass flow of air-charge, $T q$ the torque, $p_{i m}$ and $p_{\text {boost }}$ the pressure in the intake manifold and boost pressure, respectively, $\theta_{e}$ and $\theta_{i}$ the exhaust and intake cam phaser, respectively.

Figure 1 displays a conceptual control design of how the air-charge system is decentralized into individual single-input single-output (SISO) controllers, which could be in a gain-scheduled PID design [24]. Look-up tables are often used for the non-linear feedforward in the individual controllers, which is calibrated through extensive engine tests $[25,26]$. On one hand each individual SISO controller has to be calibrated, and on the other hand the requirements of the overall performance of the emissions and the driveability needs to be fulfilled. The calibration of the system can be time-consuming, and as the number of configurations increases it makes the calibration both more complex and even more time-consuming [24, 25, 27].

\subsection{Engine Models}

This thesis aims at a component and model-based methodology, to bring flexibility and the possibility to reuse previous developments, in the development of the air path control. Which would increase system knowledge as well as keeping down development time. In engine development the simulation software GT-Power is known for its possibility to reach high model fidelity but at a high computational cost [28]. However, model complexity is usually chosen in relation to its usage, for control purposes there is a trade-off between computational time and model fidelity. As an example of tailored models for usage, [29] validates and releases an open-source heavy-truck diesel engine model with the main purposes of being used in a simulation- and optimization- 
based methodology. Mean value engine models (MVEM), are defined in [30] as models where signals, parameters, and variables are averaged over one or several cycles, they were introduced for engine control in [31], and have been proven to have good enough model fidelity for control, and to be realized on a microcomputer. MVEMs are therefore usually referred to as control-oriented models $[23,30]$.

\subsection{Cross-Coupling Effects}
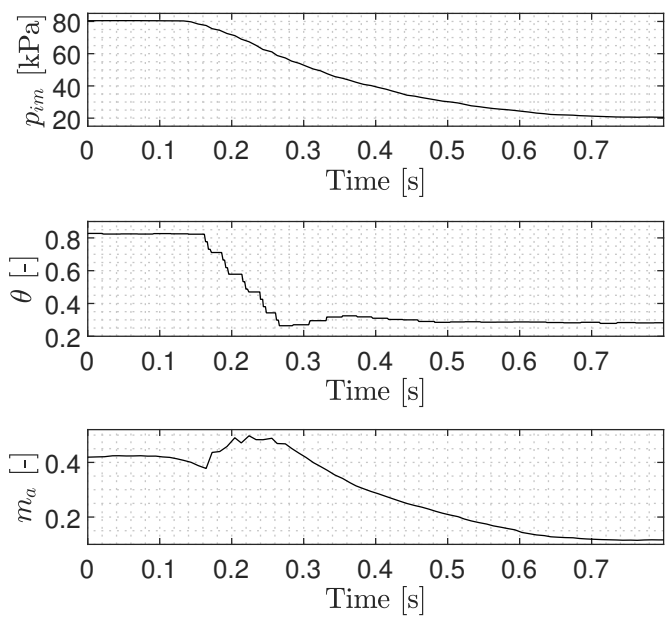

Figure 2: Measurements from real driving during engine development. Showing an increase in air mass, $m_{a}$, altough the intake manifold pressure, $p_{i m}$, is decreasing. Which demonstrates the transient interactions between the intake cam phasing, $\theta$, and the intake manifold pressure. Figure from Paper V.

Although the intake manifold pressure, $p_{i m}$, in Figure 2, from Paper V, is decreasing, there is an unwanted increase in air mass, $m_{a}$, in the beginning of the transient due to the adjusted phasing of the intake cam, $\theta$. This demonstrates an unwanted effect caused by cross-couplings in the system, and it demonstrates that there might be cross-couplings between different control loops. In this case, the intake manifold pressure and intake cam phaser loop, which needs to be handled in the control design.

Cross-coupling effects can occur both through the adding of new configurations that affect the air path, and through improved actuators. In a control design with individual controllers, a change in the configuration that is calibrated might cause a large re-calibration of the overall performance of the control loops. 
Therefore, control designs that incorporate these cross-couplings is of interest. In [32] the cross-coupling between the air-to-fuel ratio (A/F) and variable cam timing is investigated by fixating the intake throttle and have the fuel injection and cam timing as control inputs. A decentralized controller is compared to a multiple-input multiple-output controller (MIMO). To attenuate the crosscoupling between the cam actuation and the A/F, the decentralized controller has to do a trade-off between lowering the bandwidth of the cam timing actuation, or increase the bandwidth of the A/F loop. In the MIMO case, by its structure, it could potentially reduce the coupling between the cam timing and A/F control loop, without the trade-off present for the decentralized controller. This indicates that there might be performance benefits from incorporating the cross-coupling effects into the controllers.

\subsection{Turbo Control}

For a turbocharged engine, [33] concluded that the most fuel efficient strategy in the boosted region is to keep the throttle fully open and let the wastegate be the main actuator for the air mass. However, in the throttled region, the wastegate should remain fully open. In [34] a decentralized control of the throttle control and wastegate control is presented, where each individual controller is tuned using different state-feedback controllers. [35] presents another strategy for the control of the throttle and wastegate using reference governors based on linear models for constraint following. The author of this thesis has also looked into the coordination of wastegate and throttle control in [36], where measurements of the turbocharger speed was used as feedback in a cascaded control design, giving a faster feedback than the boost pressure. Another work investigating the coordination of wastegate and throttle is [37], where it is seen as a two-input one-output problem. An extra middle region is added for driveability, where both throttle and wastegate are used simultaneously compared to the most fuel efficient strategy in [33]. 


\subsection{Model Predictive Control}

Model predictive control (MPC) is a control design that receives more attention in the field of ICE control. MPC is an optimization based control design where a cost function is defined for a specific control objective, together with input and state constraints. Using the models for the states, it is able to predict the behavior of the system for a certain time horizon. Optimization techniques are then used to find the control signal that minimizes the defined cost function. This is then repeated for each iteration of the controller over a receding horizon. Papers IV and V have implemented reference governors using MPC. [38] demonstrated an MPC that controlled the intake throttle and intake cam phaser, to fulfill the torque demand while minimizing the pumping losses. An MPC, scheduled for series production, controlling the airflow using wastegate, throttle, and intakeand exhaust cam phasing was presented in [39]. In [40] the coordination of the spark timing and intake throttle for the idle speed control was handled by an MPC. The controller was demonstrated in a vehicle and showed improved performance and robustness compared to existing controllers. MVEMs were used in [41] for the air path control with the EGR valve, intake throttle, and wastegate as actuators in an MPC implementation. The control objectives are formulated to achieve the requirements from the exhaust after-treatment system. The designed MPC showed mass production maturity level and decreased the fuel consumption compared to the baseline PID control scheme. Both the baseline PID control scheme and the MPC controller had similar margin to the EU6 emission regulations. A review of MPC for ICE is presented in [42], where they conclude that MPC for multi-objective transient engine control to reduce real driving emissions is promising. The authors also states four steps needed towards the successful implementation of MPC in today's engine hardware. These steps could be summarized to:

1. Reduce model order wherever possible.

2. Select a control horizon of the MPC based on the system dynamics.

3. Select an optimal solver that fits the specific control problem.

4. Select hardware that can compute the control action within its time limits. 



\section{Chapter 3}

\section{Publications and Contributions}

A short summary of the publications and contributions from each publication in the thesis is presented in the first part. In the second part of the chapter the overall contributions in the thesis are stated.

\subsection{Publications}

The thesis is about the automotive air paths and model-based structures starting at a component level, Paper I models and controls the wastegate actuator in the air path configuration. Papers II and III changes the focus to the modeling of gas flows, where Paper II focus on the often used compressible flow model, and Paper III focus on how the flow of fresh air into the cylinders is affected by the phasing of the intake and exhaust cams. Papers IV and V focus on control problems for the air paths, and demonstrates how different control problem formulations can be handled. While Paper IV is a simulation study, Paper V demonstrates a real-time implementation of a multivariable control structure in an engine test cell, where a dependence between the actuators is taken into account.

\subsubsection{Paper I - Investigation of Performance Differences and Control Synthesis for Servo-Controlled and Vacuum-Actuated Wastegates [43]}

Investigation of the actuation of the wastegate, which is one of the actuator components of the automotive air path. The more traditionally used wastegate, 
actuated through a pressure difference over a membrane, is compared to the newer actuator using an electric servo. In the paper a state-feedback controller is developed and performs well, and because the electric motor is a linear system it behaves in the same way for movement in both directions. Additional features as soft-landing, tightening, and auto-find of the end positions, are added to the controller as well. For the more traditional actuator, the actuation of the position is found to be affected by non-linear effects, which causes the actuator to behave differently depending on the direction. Hysteresis, in the duty cycle to the pressure difference over the membrane, is one non-linear effect that is shown to be present for the actuator. The paper concludes that the proposed control of the electric servo is precise and efficient of actuating the position and this with a rather low development effort. For the pressure controlled wastegate actuator a higher development effort is needed to capture the non-linear effects, to achieve a precise and predictable control.

\subsubsection{Paper II - Analysis and Development of Compact Models for Mass Flows Through Butterfly Throttle Valves [44]}

As the title of the paper states, the paper focus on compact models for mass flow through butterfly throttle valves. The compressible flow model is often used for throttle valves, exhaust gas recirculation valves (EGR), the wastegate valve, intake- and exhaust valves, etc. Part-load maps from two different engines in an engine test cell are used for the analysis, as well as flow bench measurements for the throttle used in the Volvo engine. The advantage of the flow bench measurements is that they are free from pressure pulsations, that is otherwise present in engine test cell measurements. As has been shown before, the often used isentropic compressible flow model predicts a too high pressure ratio for when choking of the flow occurs. Both the part-load map measurements and the flow bench measurements confirm this as well. A model with the same parameters as the isentropic model, in the paper named Ohata's compressible flow model, show good agreement with the measurement data. It is formulated using the conservation of energy, momentum, and mass. However, one conclusion in the paper is that the estimation of the effective area compensates for the most significant differences in the defined $\Psi$-function. This conclusion is also drawn in Paper III. A model named the ellipse model, that previously has shown good results for compressor mass flow modeling, with an extra parameter is also presented which gives the freedom to freely define the choking pressure ratio as well as a parameter for the curvature of the function. 


\subsubsection{Paper III - Development of a Control-Oriented Cylinder Air-Charge Model for Gasoline Engines with Dual Independent Cam Phasing}

A model for the cylinder air-charge is developed and motivated using partial volumes, which fits into the MVEM framework. To analyze the mass flows during the valve overlap period, a simulation model is presented and validated to cylinder pressure measurements. Motivated by the earlier from Paper II, the standard isentropic model is compared to the Ohata model and the difference is almost eliminated thanks to the scaling. Once again confirming that the differences in the $\Psi$-function are, to some extent, compensated for in the effective area model.

Through the use of the partial volumes the physical model structure is identified, which opens the possibilities for future development of the model, and makes the assumptions used in the model visible in the equation structure.

A first phase is identified, using simulations of the overlap period, which has an inhibiting effect on the backflow of residual gases. The length of the first phase is determined by the delay of the flow reversal event at the exhaust valves, in relation to the opening event of the inlet valves. The delay of the flow reversal event is driven by the cylinder volume decrease caused by the piston movement towards the top-dead-center, in combination with the inlet valves restricting the flow generated by the volume change. This effect is present for inlet valve opening events occurring before the top-dead-center.

The proposed model is parameterized and validated against measurement data from an engine test cell. The model is compared to previous works focusing on the residual gas fraction estimation, and cylinder air-charge, where the proposed model performs best against the validation dataset.

Exchanging the displacement volume in the speed-density equation with the cylinder volume at the inlet valve closing (IVC), a visible structure in the cylinder air-charge is observed. That structure indicates that taking the volume at IVC into account separates the effects on air-charge from volume change at IVC, and the effects from the overlap period.

\subsubsection{Paper IV - Throttle Control using NMPC with Soft Intake Temperature Constraint for Knock Mitigation [45]}

A non-linear MPC (NMPC) acting as a reference governor for the throttle is presented and evaluated using simulations. The intake manifold pressure is controlled with a constraint on the peak intake manifold temperature, as intake manifold temperature is known to increase the probability of knocking. To keep the formulated control problem feasible, with model errors present, an approach 
using slack variables to implement soft constraints is demonstrated.

The paper presents an extended Kalman filter (EKF) with transient switching and a 4th order Runge-Kutta (RK4) for the prediction, to handle the slow dynamics of the intake manifold temperature sensor. When a transient is detected the measurement noise in the EKF is increased, which has the effect of increasing the weight of the information in the model, and on the contrary, decrease the weight of the information in the sensor measurement. The proposed NMPC shows promising results of using MPC based controllers as reference governors to fulfill requirements during transients. The paper also highlights the possibilities of incorporating design conditions into the control objective formulation, using MPC.

\subsubsection{Paper V - Real-Time Implementation of Non-linear MPC in Embedded Control for Engine Air-charge Throttle and Intake Cam Phase Actuator}

The paper demonstrates a multivariable NMPC, implemented in real-time, acting as a reference governor for the intake cam phasing and the intake throttle in an engine test cell. There is a cross-coupling between the two actuators as the intake manifold pressure is affected by both actuators. Therefore, the controller needs to coordinate the throttle and intake cam phasing. This is solved by formulating the control problem so that a desired intake manifold pressure is achieved while the intake cam phaser follows an intake manifold pressure dependent function. Due to this formulation the intake throttle and intake cam phaser needs to be carefully coordinated as the in- and outflow of the intake manifold can not be independently controlled. When the weights, in the optimal control problem formulation, are changed, the behavior of the controller also changes. For the case when the connection between the intake cam phaser and intake manifold pressure is relaxed, it is observed that the intake cam phaser control changes behavior, especially during negative transients as it tries to increase the outflow from the intake manifold. This paper demonstrates the flexibility and strength of model-based control, where the behavior of the controller is easily adjusted through a change in the control objective formulation. 


\subsection{Contributions}

The main contributions in the thesis of the investigation and demonstration of component and model-based methodology for air-path control development, that were stated as the aim of the thesis in Section 1.1.

1. Paper I demonstrates that development in existing components, at the actuator level, can have a significant change to a component's behavior. Linear control design methods worked well for the newer actuator that used an electric servo to control the wastegate position. The older actuator had non-linear effects that made the development effort harder.

2. In Paper II it was again proved, through measurements, that the wellknown isentropic compressible flow model predicts a too high pressure ratio for choking of the flow. The model named the Ohata model has a better agreement with the measurements, while having the same parameters as the isentropic-based model. However, Papers II and III conclude that the effective area estimation can compensate, to some extent, for the difference between the models.

3. A new MVEM model for the cylinder air-charge, with dual independent cam phasing, was developed in Paper III. In particular, it incorporates new insights about the physics in the equation structure by tracking partial volumes.

4. A flow reversal event over the exhaust valves occurring later than the inlet valve opening event (IVO) has an inhibiting effect on the residual gases trapped at the closing of the exhaust valves, affecting the volumetric efficiency. The effect is present for IVO events occurring before top-deadcenter, as the cylinder volume is decreased by the piston movement.

5. Transient temperature control aimed at knock mitigation was developed using MPC in Paper IV, which demonstrates constraint handling using MPC. To avoid risking an infeasible problem using constraints in MPC, slack variables were used.

6. Paper $\mathrm{V}$ develops and demonstrates the engineering process leading to a feasible implementation of a non-linear multivariable MPC strategy in an embedded real-time control system for an engine in a test cell.

7. Paper V further demonstrates how MPC design enables systematic design for coordination between actuators by raising the level of abstraction through the design of the control objective. 



\section{References}

[1] IEA. Tracking transport 2020. https://www.iea.org/reports/ tracking-transport-2020, 2020. [Accessed: 2021-11-29].

[2] Territoriella utsläpp och upptag av växthusgaser. https://www . naturvardsverket.se/data-och-statistik/klimat/ vaxthusgaser-territoriella-utslapp-och-upptag/. [Accessed: 2021-11-29].

[3] Cop 21. https://unfccc.int/process-and-meetings/ conferences/past-conferences/paris-climate-changeconference-november-2015/cop-21, . [Accessed: 2021-11-29].

[4] Paris agreement. https://unfccc.int/process-and-meetings/ the-paris-agreement/the-paris-agreement. [Accessed: 2021-11$28]$.

[5] Cop 26. https://unfccc.int/conference/glasgow-climatechange-conference-october-november-2021, . [Accessed: 202111-29].

[6] Cop26 declaration on accelerating the transition to $100 \%$ zero emission cars and vans. https://www.gov.uk/government/publications/ cop26-declaration-zero-emission-cars-and-vans/cop26declaration-on-accelerating-the-transition-to-100zero-emission-cars-and-vans, . [Accessed: 2021-11-28].

[7] Scania endorses global memorandum of understanding for zero-emission vehicles. https://news.cision.com/scania/r/scania-endorsesglobal-memorandum-of-understanding-for-zero-emissionvehicles,c3450771. [Accessed: 2021-11-29].

[8] Drive to zero. https://globaldrivetozero.org/. [Accessed: 202111-29].

[9] J. B. Heywood. Internal combustion engine fundamentals. McGraw-Hill Education, 2018. 
[10] F. Leach, G. Kalghatgi, R. Stone, and P. Miles. The scope for improving the efficiency and environmental impact of internal combustion engines. Transportation Engineering, 1:100005, 2020.

[11] B. Grandin and H.-E. Ångström. Replacing fuel enrichment in a turbo charged si engine: lean burn or cooled egr. Technical report, SAE Technical Paper, 1999.

[12] S. Potteau, P. Lutz, S. Leroux, S. Moroz, and E. Tomas. Cooled egr for a turbo si engine to reduce knocking and fuel consumption. Technical report, SAE Technical Paper, 2007.

[13] K. Siokos, R. Koli, R. Prucka, J. Schwanke, and J. Miersch. Assessment of cooled low pressure egr in a turbocharged direct injection gasoline engine. SAE International Journal of Engines, 8(4):1535-1543, 2015.

[14] S. Zhu, B. Hu, S. Akehurst, C. Copeland, A. Lewis, H. Yuan, I. Kennedy, J. Bernards, and C. Branney. A review of water injection applied on the internal combustion engine. Energy conversion and management, 184:139-158, 2019.

[15] T. Goto, R. Isobe, M. Yamakawa, and M. Nishida. The new mazda gasoline engine skyactiv-g. MTZ worldwide eMagazine, 72(6):40-47, 2011.

[16] T. Lake, J. Stokes, R. Murphy, R. Osborne, and A. Schamel. Turbocharging concepts for downsized di gasoline engines. Technical report, SAE Technical Paper, 2004.

[17] D. B. Roth, P. Keller, and M. Becker. Requirements of external egr systems for dual cam phaser turbo gdi engines. Technical report, SAE Technical Paper, 2010.

[18] K. Akima, K. Seko, W. Taga, K. Torii, and S. Nakamura. Development of new low fuel consumption $1.81 \mathrm{i}$-vtec gasoline engine with delayed intake valve closing. Technical report, SAE Technical Paper, 2006.

[19] Ž. Ivanič, F. Ayala, J. Goldwitz, and J. B. Heywood. Effects of hydrogen enhancement on efficiency and nox emissions of lean and egr-diluted mixtures in a si engine. SAE transactions, pages 138-149, 2005.

[20] M. Sassano, T. E. Passenbrunner, M. Hirsch, L. del Re, and A. Astolfi. Approximate optimal control of the air path of a diesel engine. In 2012 American Control Conference (ACC), pages 4204-4209. IEEE, 2012.

[21] T. Johnson. Vehicular emissions in review. SAE International Journal of Engines, 9(2):1258-1275, 2016.

[22] N. Hooftman, M. Messagie, J. Van Mierlo, and T. Coosemans. A review of the european passenger car regulations-real driving emissions vs local air quality. Renewable and Sustainable Energy Reviews, 86:1-21, 2018.

[23] L. Guzzella and C. Onder. Introduction to modeling and control of internal combustion engine systems. Springer Science \& Business Media, 2009. 
[24] A. Kwiatkowski, H. Werner, J. Blath, A. Ali, and M. Schultalbers. Linear parameter varying pid controller design for charge control of a spark-ignited engine. Control Engineering Practice, 17(11):1307-1317, 2009.

[25] B. Ashok, S. D. Ashok, and C. R. Kumar. A review on control system architecture of a si engine management system. Annual Reviews in Control, 41:94-118, 2016.

[26] E. G. Gonzalez, J. A. Florez, and S. Arab. Development of the management strategies of the ecu for an internal combustion engine: computer simulation. $\mathrm{Me}$ chanical systems and signal processing, 22(6):1356-1373, 2008.

[27] A. Helmantel, D. Dahl, F. Wemmert, and M. Morén. The new volvo mild hybrid miller engine. MTZ worldwide, 82(4):16-23, 2021.

[28] L. Gamma Technologies. Gt-power engine simulation software. https: //www.gtisoft.com/gt-suite-applications/propulsionsystems/gt-power-engine-simulation-software/, 2021. [Accessed: 2021-11-28].

[29] K. Ekberg, V. Leek, and L. Eriksson. Modeling and validation of an open-source mean value heavy-duty diesel engine model. Simul. Notes Eur., 28(4):197-204, 2018.

[30] L. Eriksson and L. Nielsen. Modeling and control of engines and drivelines. John Wiley \& Sons, 2014.

[31] E. Hendricks. A compact, comprehensive model of large turbocharged, two-stroke diesel engines. SAE transactions, pages 820-834, 1986.

[32] A. Stefanopoulou. Modeling and control of advanced technology engines. $\mathrm{PhD}$ thesis, University of Michigan, 1996.

[33] L. Eriksson, S. Frei, C. Onder, and L. Guzzella. Control and optimization of turbocharged spark ignited engines. IFAC Proceedings Volumes, 35(1):283-288, 2002.

[34] A. Y. Karnik, J. H. Buckland, and J. S. Freudenberg. Electronic throttle and wastegate control for turbocharged gasoline engines. In Proceedings of the 2005, American Control Conference, 2005., pages 4434-4439. IEEE, 2005.

[35] U. Kalabic, I. Kolmanovsky, J. Buckland, and E. Gilbert. Reference and extended command governors for control of turbocharged gasoline engines based on linear models. In 2011 IEEE International Conference on Control Applications (CCA), pages 319-325. IEEE, 2011.

[36] R. Holmbom, B. Liang, and L. Eriksson. Implications of using turbocharger speed sensor for boost pressure control. IFAC-PapersOnLine, 50(1):11040-11045, 2017. 
[37] P. Gorzelic, E. Hellström, A. Stefanopoulou, L. Jiang, and S. Gopinath. A coordinated approach for throttle and wastegate control in turbocharged spark ignition engines. In 2012 24th Chinese Control and Decision Conference (CCDC), pages 1524-1529. IEEE, 2012.

[38] M. Kang and T. Shen. Model predictive control for automotive gasoline engines. In 2017 13th IEEE International Conference on Control \& Automation (ICCA), pages 654-659. IEEE, 2017.

[39] A. Bemporad, D. Bernardini, R. Long, and J. Verdejo. Model predictive control of turbocharged gasoline engines for mass production. Technical report, SAE Technical Paper, 2018.

[40] S. Di Cairano, D. Yanakiev, A. Bemporad, I. V. Kolmanovsky, and D. Hrovat. Model predictive idle speed control: Design, analysis, and experimental evaluation. IEEE Transactions on Control Systems Technology, 20(1):84-97, 2011.

[41] J. Dahl, H. Wassén, O. Santin, M. Herceg, L. Lansky, J. Pekar, and D. Pachner. Model predictive control of a diesel engine with turbo compound and exhaust after-treatment constraints. IFAC-PapersOnLine, 51(31):349-354, 2018.

[42] A. Norouzi, H. Heidarifar, M. Shahbakhti, C. R. Koch, and H. Borhan. Model predictive control of internal combustion engines: a review and future directions. Energies, 14(19):6251, 2021.

[43] B. Liang, R. Holmbom, and L. Eriksson. Investigation of performance differences and control synthesis for servo-controlled and vacuum-actuated wastegates. In WCX ${ }^{\mathrm{TM}}$ 17: SAE World Congress Experience. SAE International, mar 2017. doi: https://doi.org/10.4271/2017-01-0592.

[44] R. Holmbom and L. Eriksson. Analysis and development of compact models for mass flows through butterfly throttle valves. In WCX World Congress Experience. SAE International, apr 2018. doi: https://doi.org/10.4271/2018-01-0876.

[45] R. Holmbom and L. Eriksson. Throttle control using nmpc with soft intake temperature constraint for knock mitigation. IFAC-PapersOnLine, 54(10):203-208, 2021. 
Papers 


\section{Papers}

The papers associated with this thesis have been removed for copyright reasons. For more details about these see:

https://doi.org/10.3384/9789179291464 


\section{Dissertations \\ Division of Vehicular Systems \\ Department of Electrical Engineering \\ Linköping University}

No. 1 Magnus Pettersson, Driveline Modeling and Control, 1997.

No. 2 Lars Eriksson, Spark Advance Modeling and Control, 1999.

No. 3 Mattias Nyberg, Model Based Fault Diagnosis: Methods, Theory, and Automotive Engine Applications, 1999.

No. 4 Erik Frisk, Residual Generation for Fault Diagnosis, 2001.

No. 5 Per Andersson, Air Charge Estimation in Turbocharged Spark Ignition Engines, 2005.

No. 6 Mattias Krysander, Design and Analysis of Diagnosis Systems Using Structural Methods, 2006.

No. 7 Jonas Biteus, Fault Isolation in Distributed Embedded Systems, 2007.

No. 8 Ylva Nilsson, Modelling for Fuel Optimal Control of a Variable Compression Engine, 2007.

No. 9 Markus Klein, Single-Zone Cylinder Pressure Modeling and Estimation for Heat Release Analysis of SI Engines, 2007.

No. 10 Anders Fröberg, Efficient Simulation and Optimal Control for Vehicle Propulsion, 2008.

No. 11 Per Öberg, A DAE Formulation for Multi-Zone Thermodynamic Models and its Application to CVCP Engines, 2009.

No. 12 Johan Wahlström, Control of EGR and VGT for Emission Control and Pumping Work Minimization in Diesel Engines, 2009.

No. 13 Anna Pernestål, Probabilistic Fault Diagnosis with Automotive Applications, 2009.

No. 14 Erik Hellström, Look-ahead Control of Heavy Vehicles, 2010.

No. 15 Erik Höckerdal, Model Error Compensation in ODE and DAE Estimators with Automotive Engine Applications, 2011.

No. 16 Carl Svärd, Methods for Automated Design of Fault Detection and Isolation Systems with Automotive Applications, 2012. 
No. 17 Oskar Leufvén, Modeling for Control of Centrifugal Compressors, 2013.

No. 18 Christofer Sundström, Model Based Vehicle Level Diagnosis for Hybrid Electric Vehicles, 2014.

No. 19 Andreas Thomasson, Modeling and control of actuators and co-surge in turbocharged engines, 2014.

No. 20 Emil Larsson, Model Based Diagnosis and Supervision of Industrial Gas Turbines, 2014.

No. 21 Andreas Myklebust, Dry Clutch Modeling, Estimation, and Control, 2014.

No. 22 Tomas Nilsson, Optimal Engine Operation in a Multi-Mode CVT Wheel Loader, 2015.

No. 23 Daniel Jung, Diagnosability Performance Analysis of Models and Fault Detectors, 2015.

No. 24 Martin Sivertsson, Optimal Control of Electrified Powertrains, 2015.

No. 25 Peter Nyberg, Evaluation, Generation, and Transformation of Driving Cycles, 2015.

No. 26 Kristoffer Lundahl, Models and Critical Maneuvers for Road Vehicles, 2016.

No. 27 Vaheed Nezhadali, Modeling and Optimal Control of Heavyduty Powertrains, 2016.

No. 28 Xavier Llamas, Modeling and Control of EGR on Marine TwoStroke Diesel Engines, 2018.

No. 29 Sergii Voronov, Machine Learning for Predictive Maintenance, 2020.

No. 30 Victor Fors, Autonomous Vehicle Maneuvering at the Limit of friction, 2020.

No. 31 Fatemeh Mohseni, Decentralized Optimal Control for Multiple Autonomous Vehicles in Traffic Scenarios, 2021.

No. 32 Mahdi Morsali, Trajectory Planning for an Autonomous Vehicle in Multi-Vehicle Traffic Scenarios, 2021. 
No. 33 Kristoffer Ekberg, Modeling and Optimal Control for Dynamic Driving of Hybridized Vehicles with Turbocharged Diesel Engines, 2021.

No. 34 Pavel Anistratov, Autonomous Avoidance Maneuvers for Vehicles using Optimization, 2021.

No. 35 Iman Shafikhani, Energy Management Strategy Design for Series Hybrid Electric Vehicles, 2021. 




\title{
FACULTY OF SCIENCE AND ENGINEERING
}

\author{
Linköping Studies in Science and Technology \\ Dissertation No. 2195, 2022 \\ Department of Electrical Engineering \\ Linköping University \\ SE-581 83 Linköping, Sweden \\ www.liu.se
}

